\title{
The Great Phenomenon of Online Sirri Marriage for Male And Female
}

\author{
Nasaiy Aziz \\ UIN Ar-Raniry, Darussalam Banda Aceh \\ nasaiyaziz76@gmail.com
}

\begin{abstract}
Online sirri marriage is a marriage which is organized through skype or other social media without documentation from the marriage registration council. So far, the practice of online sirri marriage in Indonesia is very apprehensive and to be serious problem in the society. It happened because the regulation that control marriage which is stated in law (UU) of marriage and compilation of Islamic law tend to be ignored. The requirement of the guardian (Wali) as regulated by Islamic law is ignored. However, the online sirri marriage is organized by involving marriage celebrant (penghulu) as magistrate guardian (wali hakim) who married off which is not detected by the woman's parents, her guardian, and marriage registrar. The practice of online siri marriage is performed by using skype media and other social media that the face of penghulu and the two brides can be seen directly. The consequences that will arise are uncertainty of law and law protection, especially for women and children who could not claim their rights when family conflict occurred. This kind of marriage is legal (sah) when it is implemented in accordance with the rules and prerequisites in Islamic law. However, the phenomenon of sirri marriage which is performed arbitrarily contradicts the Islamic law, because the completeness one of the pillars of marriage that is involvement of guardians is not fulfilled as well as many mafsadah occurs. In addition, online sirri marriage is also not recognized by the state, because it could not be proven by the marriage certificate.
\end{abstract}

Keywords: sirri marriage; online media; male; female; society

\section{Introduction}

Marriage is considered legal and valid when it meet all of syara' and legislation requirements. Marriage which is committed outside the rule is illegal according to Islamic law (syara') and it is not recognized by the State (having no legal force), this type of marriage is often called online sirri marriage. The phenomenon of online sirri marriage recently implemented has disturbed the public regarding its legal status according to the law of religion and state. The practice of sirri marriage mostly committed over the phone or application of smartphone gadget such as skype. By using this media, marriage celebrant, two brides, and witnesses can watch directly the marriage solemnization. However, the problem is the marriage guardian which is provided in justifying the marriage is the service of online marriage celebrat. While the parents or guardians do not know that his daughter has married. 
According to them, online sirri marriage is organized to avoid the occurrence of adultery. Therefore, they choose to perform the marriage on this way even though without confirmation from their parents.

Through this paper the writer try to focus on how the online sirri marriage is implemented nowadays? what is the impact of this marriage? How islamic law and positive law view this kind of marriage on mafsadah perspective?

\section{Theoritical Riview}

The term of online sirri marriage is the combination of online, sirri and marriage. Simply, According to syara' marriage can be interpreted as;

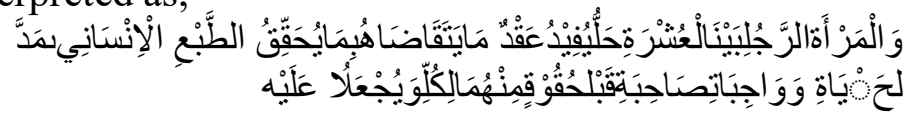

That is aqad that allow man and woman in mingling by considering aspects of humanity, rights and obligations.

Related to this discussion, when it is viewed from the context that stated by the law, of course the definition of marriage is more comprehensive. The interpretation of nikah or marriage for Indonesian Muslims is inseparable from the two main formulations, as stated in Law (UU) number 1 year 1974 about Marriage and in INPRES number 1 year 1991 about Islamic Law compilation. In this formulation, marriage is interpreted not only as a contract (aqad) that allows intercourse or intimate relationship, but it has a broader meaning. From definition of marriage formulated in both criteria that have become the positive law of Indonesia can be concluded that marriage is a sacred bond between a man and a woman. Committing marriage is an act of worship that has been ordered by Allah. Therefore, marriage should be saved, maintained and carried out in accordance with the applicable rules regulated in Islamic law and which has become a positive law of Indonesia. The word of sirri which means secret is the opposite of word 'jahri' that means openly (open to the public). According to the terminology of fiqh of Maliki as quoted by Masjfuk Zuhdi, sirri marriage is a marriage which the husband, the witnesses keep his marriage secret from his wife or his jama'ah, even his family. While according to the positive law, sirri marriage is a marriage that is implemented by not meeting the requirements and procedures of legislation. This means the marriage is not registered or authorized by marriage officials; the marriage is classified as unlawful marriage by the state. As stated in Pasal 2 Paragraph (2) Law (UU) Number 1 Year 1974 About Marriage.

Ulama Consultative Council of Aceh, states that sirri marriage is a marriage which is not performed in front of marriage registry officer and not registered at the Sub-districts Office of Religious Affairs or at other authorized institutions. Furthermore, Ulama Consultative Council of Aceh declares in Fatwa No. 01 Year 2010 About Sirri marriage, there are two kind of sirri marriage in sharia law; sirri marriage that meets all of the principle (rukun) and prerequisites (syarat), and sirri marriage where the rules is not fulfilled completely. From the definition above, sirri marriage is a marriage that performed by a man and a woman where the state law and Islamic law criteria is not fulfilled. The term "online" or "internet" comes from English, internet which is etymologically derived from word of "inter" means "inside" and word of "net" that means net, nets, hair net, network, and profit. Internet in term of etymology stands for International Network that means internationally connected networks. 
While in term of terminology, internet is a network that connects other networks all around the world. This network consists of Small-scale networks (PC) and large networks. Based on the explanation above can be concluded that online sirri marriage is a sirri marriage performed by a man and a woman through the internet by having no guardian, not registered at the local KUA and secretly committed and undetected female family. Therefore, in online sirri marriage, there are no guardians and witnesses of the female family participating the marriage akad, however, the guardian on this kind of marriage is contracted guardian that give marriage service for every people come.

\section{Discussion}

Before online marriage is performed, the groom and the bridge have been known each other. The process of marriage contract (akad) is conducted by long-distance marriage. Where the position of the brides couple and marriage provider is different. However, they can see the process of marriage through skype application available on HP with a support device by using front camera that can be directed directly to their face. At the process of marriage contract, there is no guardian involved as one of principle required Islamic law. Based on how the marriage is conducted, it can be seen that their marriage is performed without marriage proposal or khitbah in fiqh context. They know each other at some of entertainment venues, and try to communicate each other in short or long duration of time. The man did not come to the woman's house in order to ask for her parent's agreement, yet he try to find the marriage provider (penghulu) to marry them off. Khitbah, In Islamic law is not a legal requirement of marriage, if marriage is conducted without a khitbah, marriage is lawful. Khitbah according to Jumhur (the majority of fuqaha) is allowed, as the Qur'an says "There is no blame upon you whether you hint at a marriage proposal to such women or keep the proposal hidden in your hearts "(Surah al-Baqarah: 235).

Besides having no khitbah, there is also no wedding ceremony (walimatu al-urus') conducted as the confirmation that they are already married. Whereas wedding ceremony (walimatul 'urus) has a magical power for those conduct it. In addition to the absence of khitbah and walimatul 'ūrūs, online sirri marriage also having no legal guardian from relatives or female family. A marriage without a guardian becomes illegal due to one of marriage principle is not fulfilled. Based on the discussion above, it can be seen that marriage is not a usual relationship contract between a man and woman, but marriage is one of the legal acts that must meet the prerequisites and rules. The implementation of online sirri marriage is not legal considering the elements of marriage, such as marriage guardian and witnesses. The existence of a guardian for women determines the legality of marriage. Although online provider service is used as guardian (hakīm's guardians), it doesn't meet the main criteria of guardian as stated by most scholars and the rule of law.

Something that performed without following the appropriate procedure will have some implications. In the context of online sirri marriage conducted by a man and woman without following formal procedures, will give some consequences toward that married couple. Generally, the law consequences that will can be classified into two categories, namely the internal and external law consequences.

As the main and the first consequences of this kind of marriage, the status of marriage is illegal according to Islamic law and positive law, because of no woman's parents or guardian 
confirmation and recognized by the states. There is no authentic evidence as married documentation. By having no authentic evidence indicating that online sirri marriage is a kind of marriage performed a man and a woman without following the state law, and even contradicts with Islamic law. The marriage is not identified by the States; this marriage is not registered and conducted by following the procedures as regulated. In addition, the marriage doesn't have law protection, as stated in Pasal 6 Ayat (2) and Pasal 7 Ayat (1) of KHI.

Based on what marriage registration is an urgent point to be implemented. The marriage which is not performed in front of authorized officials will not have authentic certificate that can be used to proof the marriage. By having no authentic certificate, they will not have an administrative prerequisites required to apply for birth certificate, and so forth.

Actually, marriage registration is realized by Islamic law reviewers is very important to ensure the regularity and legal certainty in the community. The problem is where marriage registration should be included, whether in the scope of principle (rukun) or in administrative prerequisites. If it is included in the scope of marriage principle, could be assumed that it will be rejected, especially by traditional scholars who think that the principle (rukun) as something that is very central and a must. It must be supported by the best argumentation both from the Qur'an and Hadith. In order to avoid a difficult debate, the marriage registration should be integrated with the presence of witnesses. And there is no new marriage principle (rukun) occurred. For the second consequence, there is no kind of rights and obligations because they have never married, and because of their marriages are illegal according to Islamic law. A legal marriage will admit the rights and obligations from the husband and wife. So that there is no rights and obligations at online sirri marriage. Therefore, the rights and obligations will be valid when the marriage is performed legally according to Islamic law. Another internal consequence is that if an online marriage is performed illegally, it will give an impact on the illegality of marriage, as well as sexual relations they do is a forbidden relationship. Furthermore, this action is categorized as adultery and the child who is born from result of adultery is adulterous child. Another internal consequence is when a divorce occurs, where the wife should be entitled the 'iddah nafaqa as mentioned in Pasal 149 (a), but with the unauthorized marriage the right shall be ignored. Beside of 'iddah nafaqa case after divorce, the next internal consequence of online sirri marriage is could not be distributed the joint marital property. Pasal 96 ayat (1) of KHI states that if a spouse dies during a divorce, then one half of the joint property becomes the right of couples who is still alive. Furthermore, in Pasal 97 of KHI stated that a widow or widower is a compulsory heir entitled to receive one half of common property as long as it is not specified the other things in the marriage agreement. Thus, by having no marriage certificate, it is very difficult to claim the joint marital property.

One of the most troublesome external consequences of sirri online marriage in Islamic law is the recognition of children's lineage determination (nasab). The unlawful marriage because of having no confirmation of marriage from the parents or guardian when the marriage contract (aqad) is conducted. Thus, the child is categorized as adultery children and the nasab of children is attributed directly to his mother. Likewise the child is recognized by the State as a legitimate child according to positive law, because the marriage is not registered at the registry office. The recognition from Islamic law and positive law would directly affect other things in his life, such as facing difficulty in applying for birth certificate that nowadays is indispensable. Another important consequence, in the concept of law, is the 
caregiver's uncertainty and preservation from both parents who can fulfill all their needs; Such as affection, education, donation, etc.

In Islamic teachings, the child protection, which is known as hazānah, is an obligation for both parents. And it is very important to be implemented. Therefore, they must have the ability, adequacy and some certain prerequisites to be fulfilled. The explanation in detailed about hazāanah is stated in Pasal 105 and 156 (d) of KHI. Furthermore, the another external consequence from online sirri marriage is no inheritance between married couples, lack of legal protection for wives and children, and the rights of wife and children is neglected since having no authentic certificate that can prove marital status. Inheritance is the issue after a person passes away. The heirs have a right to the property left. Yet if the marriage performed is online sirri marriage, there is no kind of inheritance for the children. Because of having no marital bond, then the inheritance could not be claimed.

According to Islamic law, there are three causes that make a person get inheritance. The first one is the real relative (lineage determination), such as parents, children, brother, uncle, and so on. Second, Marriage, that is a legal marriage contract (syar'i) between a man and woman, whether they have sexual intercourse or not. While the illegal marriage, could not be the cause to get the right of inheritance. Third, Al-walā ', which is the kinship relationship in law. It is also called as walā 'al-'itqī and walā' an-ni'māh. In other words, to free the slaves is one of inheriting causes.

The next internal and external consequence is no legal certainty for the wife and children. In this case, the wife and child can't claim anything from their father if a divorce is occurred. For example, Pasal 96 Ayat (1) of KHI states that if a spouse dies during a divorce, then one half of the joint property becomes the right of couples who is still alive. Some obstacles will be faced because of the divorce case, determination of inheritance and distribution of joint property as stated by law and should be processed in the Religious Courts. According to Pasal 39 Paragraph (1) UU No. 1 Year 1974 about marriage, a divorce is can be held In front of the Court trial after the reconciliation process is failed. Therefore, the problem is when the wives try to prove marital status in the court. Because there is no authentic proof authorized by certain official, it will obstruct to get their rights. Another consequence that arises is about the status of children from the practice of online sirri marriage. The children have only a civil relationship with their mother. Pasal 100 of KHI states "The child born outside marriage has only a nasab relationship with his mother and his mother's family". Therefore, whatever related to the private law, such as inheritance is only from the mother's family.

\section{Conclusion}

Nowadays online sirri marriage is performed by using Skype and other social media with the help of illegal marriage official (penghulu). The bride candidate must register first at the online sites of sirri marriage. Then the marriage can be implemented at the time specified without have to come and meet marriage official (penghulu) directly, but it can be only through Skype or other social media. From the results of the analysis shows that the main internal legal consequences of online sirri marriage, according to Islamic law, is the prohibition of sexual relationship between them, due to the lack of one marriage pillars that is the agreement of the woman's parents or guardian. Likewise, according to positive law is 
having no legal protection by the state since the implementation of the marriage is not registered. Another consequence, external consequence, both according to Islamic law and the positive law, the children's lineage and another civil rights will be attributed to the mother.

\section{References}

Abdul Somad, Hukum Islam Penormaan Prinsip Syari'ah dalam Hukum Indonesia, (Jakarta: Kencana, 2010.1

Abdul Rahman Ghozali, Fiqh Munakahat, Jakarta: Kencana, 2010.

Abdul Manan, Aspek-Aspek Pengubah Hukum, Jakarta: Kencana Prenada Media Group, 2005.

Abdul Aziz Dahlan, Ensiklopedi Hukum Islam, Jakarta: Ichtiar Baru van Hoeve, 1996.

Abdul Rahman Ghazali, Fiqh Munakahat, Jakarta: Kencana Prenada Meida Group, 2012.

Abu Bakar Jabir al-Jazairi, Minhajul Muslim; Pedoman Hidup Seorang Muslim, terj: Ikhwanuddin Abdullah \& Taufiq Aulia Rahman, Jakarta: Ummul Qura, 2014.

Abdul Madjid Mahmud Mathlub, al-Wajiz fi Ahkam al-Usrah al-Islamiyah; Penduan Hukum Keluarga Sakinah, transl: Harits Fadhly \& Ahmad Khotib, Surakarta: Era Intermedia, 2005.

Abu Bakar Ahmad bin Husain bin 'Ali Al-Baihaqi, Sunan Al-Kubra, Vol. 7, Bairut: Dar AlKutub Al-'Ulumiyyah, 1994.

Ibnu Hajar al-‘Asqolani, Terjemah Bulugul Maram, Bogor: Pustaka Ulil Al-Bab, 2007.

Mardani, Akad Nikah Melalui Telepon, Televisi, dan Internet dalam Perspektif Hukum Islam, dalam Bunga Rampai Hukum Aktual, Jakarta: Ghalia Indonesia, 2008.

Masjfuk Zuhdi, Nikah Sirri, Nikah di Bawah Tangan, dan Status Anaknya Menurut Hukum Islam dan Hukum Positif, Jurnal Mimbar Hukum Aktualisasi Hukum Islam, Jakarta: Al-Hikmah \& Ditbinbapera Islam, 1996.

M. Ali Hasan, Pedoman Hidup Berumah Tangga dalam Islam, Jakarta: Siraja, 2006.

Syaikh Hasan Ayyub, Fikih Keluarga, transl. M. Abdul Ghoffar, Jakarta: Al-Kautsar, 2005.

Tim Redaksi Nuansa Aulia, Kompilasi Hukum Islam; Hukum Perkawinan, Kewarisan dan Perwakafan, Jakarta: Nuansa Aulia, 2008.

Wahbah Zuhaili, Fiqh Islam Waadillatuhu: Pernikahan, Talak, Khulu', Ila', Li'an, Zihar dan Masa Iddah, transl: Abdul Haiyyie Al-Kattani, et al, Vol. 9, Jakarta: Gema Insani, 2011. 